\title{
Import substitution in Brazil between 1995 and 2000
}

\section{Renato Baumann and Ana Maria de Paiva Franco}

$\mathrm{T}$ he Brazilian economy suffered major changes in the second half of the 1990s, when price stabilization, trade liberalization with an overvalued exchange rate and privatizations altered productive processes in various sectors and led to import substitution, among other phenomena. Import substitution occurred in particular following the reform of the exchange-rate regime, which entailed a substantial devaluation in early 1999. This article seeks to measure the intensity of that process, distinguishing effects that can be related to exchange-rate variations induced by relative prices alone (spontaneous import substitution) from those that reflect levels of effective protection (import substitution induced by trade policy).
Renato Baumann,

Director,

ECLAC Office in Brasilia

•renato.baumann@cepal.org Ana Maria de Paiva Franco, Ph.D. candidate,

University of São Paulo

• anafranc99@hotmail.com 


\section{Introduction}

The need to reduce the country's external vulnerability, through ever larger trade surpluses, and to strengthen the productive chain in certain key sectors of the economy, has been a topic of recurrent debate both in governmental and business domains, and among institutions linked to industry and foreign trade (Melo, Rios and Gutiérrez, 2001; Rosa, 2001; Alem, Barros and Giambiagi, 2002). While there is consensus on the need to make products more competitive on the domestic and world markets, there are very clear differences of opinion as to the appropriate degree of State intervention in the process. ${ }^{1}$

In 1995-2000 a number of sectors of the Brazilian economy showed signs of an import substitution process, stemming from the devaluation of the real in 1999 (Moreira and Puga, 2001; Levy and Serra, 2002). This article analyses data from that period to verify the existence of such a process and decide whether it occurred spontaneously or as a result of the Government's interventionist policies. For this

${ }^{1}$ For a debate on a new industrial policy profile in Brazil, see Barros and Goldenstein (1997) and Alem, Barros and Giambiagi (2002)

FIGURE

Brazil: Trend of the real exchange rate, 2000-2006

$(\text { Deflator: IPCA) })^{\mathrm{a}}$

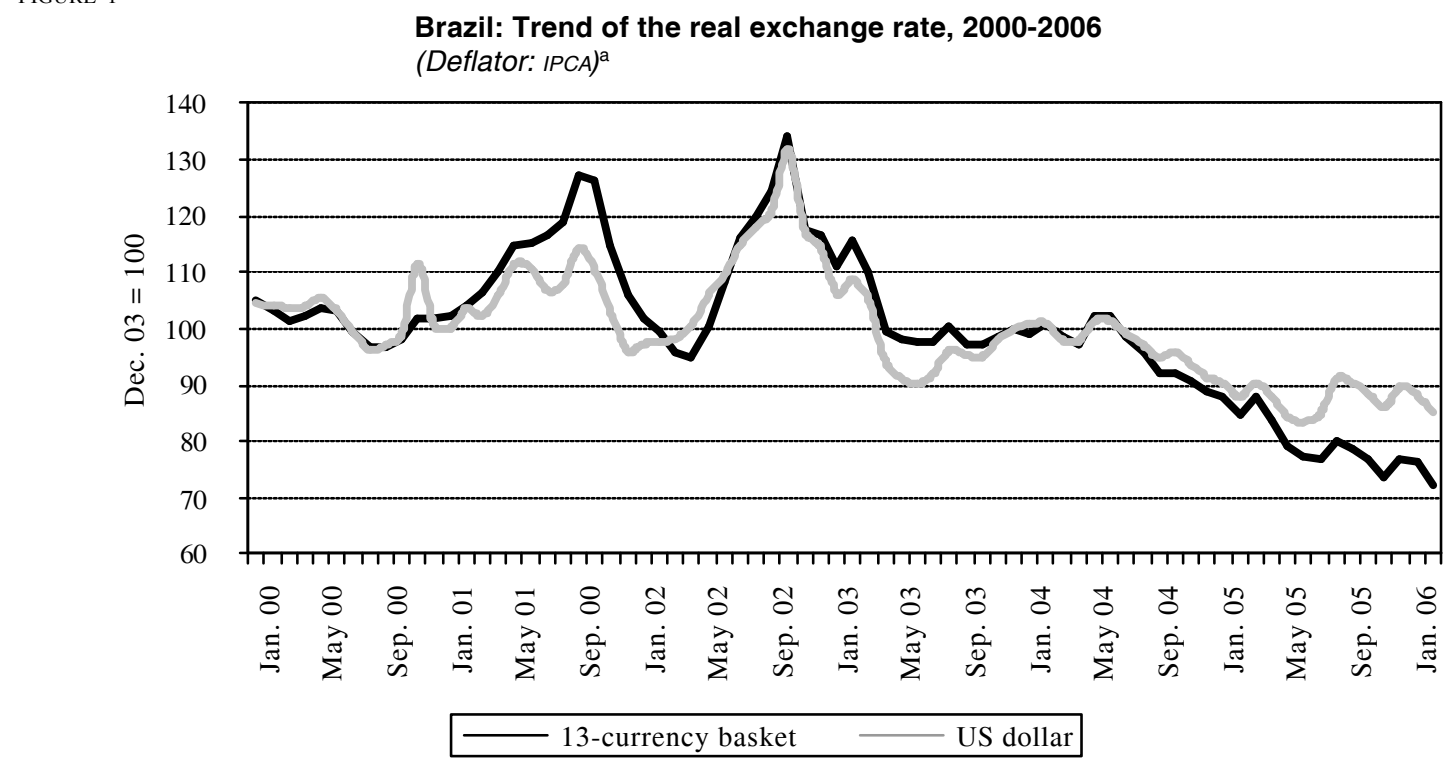

Source: www.funcex.com.br.

${ }^{a}$ IPCA: Extended national consumer price index. purpose, an adjusted linear regression model was applied to the industry data set, using tariff levels and exchange rates as explanatory variables, and a measure of import substitution as the dependent variable.

The analysis is limited to the second half of the 1990 s, since the latest available data on rates of effective protection in Brazil are for 1998.

As shown in figure 1, the exchange rate fluctuated sharply after 1998, and in 2002 there was overshooting as the real devalued against the dollar and a 13-currency basket of Brazil's main trading partners, before rebounding strongly.

Even if trade policy is considered constant in that period, it is reasonable to assume that the spontaneous import substitution process would have changed direction between 2000-2002 and 2003-2005. The available indicators on import coefficients in manufacturing industry allow a number of indirect conjectures to be made, as shown in table 1.

The import coefficient in manufacturing production peaked in 2001 and then began to fall. Although the effects in terms of import substitution can only be verified through specific estimations, the type of analysis presented in this paper is feasible only up to 2000 for the reasons mentioned above. 
TABLE 1

Brazil: Import coefficients of manufacturing industry

\begin{tabular}{lcc}
\hline Year & Total & Total excluding Agriculture \\
\hline Average 1995-99 & 11.6 & 12.1 \\
2000 & 12.7 & 13.1 \\
2001 & 14.7 & 15.1 \\
2002 & 13.0 & 13.6 \\
2003 & 11.0 & 11.7 \\
2004 & 10.9 & 12.1 \\
\hline
\end{tabular}

Source: www.funcex.com.br.

The rest of this article is organized as follows: section II introduces the concept of import substitution as defined in the specialist literature, and section III summarizes how Brazil's trade policy changed from 1998 onwards as it opened its market to world trade. Section IV defines the measure of import substitution to be used in the rest of the article, based on production and import data from a number of sectors of Brazilian manufacturing industry in 1989-2000; it then examines the relation between tariff levels, the exchange rate and import substitution. Section V analyses the effects of the effective tariff and the real effective exchange rate index (i.e. the real against a basket of 13 currencies) on the import substitution index for 34 sectors of manufacturing industry over the period 1995-2000. Section VI presents the main conclusions and policy recommendations.

\section{II}

\section{The concept of import substitution}

Definitions of the terms "import substitution", "protection" and "promotion" - which date back to the debates on developing-country trade policies in the second half of the nineteenth century- are often ambiguous. Tavares (1977) defines import substitution as a development process whereby, in response to external trade constraints such as those experienced by the Southern Cone countries in the four post-war decades, the aim was to rapidly replicate the industrialization experience of the developed countries, albeit under different historical conditions.

The general aim was to build an economy that was flexible and diversified enough to overcome crises, create real and continuous growth opportunities and generate welfare for the population. The basic rationale of the import-substitution strategy is that, as developing countries industrialize, their industries need protection against competition from imported products (Bruton, 1989, p. 1603). According to Chenery, as quoted by Díaz-Alejandro (1975), import substitution takes place when the import share of the supply of a specific good shrinks in relation to that of domestic production, either because a new tariff is levied on imports of that product, or because devaluation raises import prices, or for other reasons, including the interruption of trade operations because of war.

Desai (1969) distinguishes two types of import substitution measure: (i) measures that compare to an optimum; and (ii) others that simply describe changes in the domestic pattern of imports and production.
Import substitution does not refer to a simple operation in which certain items are withdrawn from the import basket, or their volume reduced, to be replaced by domestic substitutes. To understand it in this way might suggest a strategy of eliminating all imports, i.e. autarchy. Instead, it is a complex process in which other goods take the place of the substituted products, and, as the process unfolds, derived demand for imports grows (for intermediate and capital goods), possibly resulting in even greater dependency on abroad. The apparent substitution may thus conceal the essence of the phenomenon:

(i) Although the volume or share of certain products in the import basket may not decrease, substitution can occur as domestic production expands and provides a larger share of total supply, with a consequent reduction in the economy's import coefficient.

(ii) Comparative analysis of the import basket between different periods may be distorted as new products emerge on the international market. One therefore needs to identify whether an increase in imports of a given product displaces domestic production, or whether it involves a new product that is not made in the country.

(iii) Imports of certain products may decrease as a result of trade sanctions, discriminatory policy or other factors of that type. There will only be real import substitution if domestic production is stimulated. 
(iv) The real or effective substitution is generally much less than what appears in terms of a decline in imports of specific products. Domestic production of a given good only replaces part of the value added that was previously generated outside. Accordingly, a dynamic increase in the derived demand for imports may outweigh the foreignexchange saving obtained through the replacement production.
Consequently, when speaking of promoting import substitution, it needs to be understood, firstly, that domestic production must be stimulated; and, secondly, that the process may actually worsen the trade balance and result in greater foreign dependency, both because of the need to import intermediate and capital goods, and because of the effect on demand arising from the additional income generated by the increase in domestic production in the benefited sectors (Tavares, 1977).

\section{III}

\section{Changes in Brazil's trade regime: from market reserve to economic openness}

This article makes a distinction between two types of import substitution process: induced and spontaneous.

Import substitution can be induced through interventionist policies to stimulate the domestic production of a specific product that the country currently imports. Apart from offering favourable prices, one of its effects is to create barriers to competitive imports. Spontaneous substitution, in contrast, occurs naturally when the relative prices of domestic production fall in relation to foreign production, thus making the domestic product cheaper.

A change in relative prices may be linked either to greater productivity gains in the domestic industry or to a depreciation of the domestic currency against foreign currencies; both make the domestically manufactured product relatively more competitive.

The import substitution model that prevailed in Brazil until the late 1980s used numerous policy tools to keep out foreign products, including import licences, quotas, foreign-exchange auctions and tariffs. From then on, however, far-reaching changes were made to foreign-trade policy for the purpose of opening up the domestic economy. That process gathered pace in the following decade, when several trade agreements were signed, including the treaty creating the Southern Common Market (MERCOSUR) in 1991.

The policy to reduce import barriers was implemented in three stages (Kume, Piani and Souza, 2000, pp. 1-10), corresponding to the periods 1988-1989, 1990-1993 and 1994 onwards. The economic liberalization process faltered in 1995-98, following the Mexican crisis in December 1994, when it became unviable to finance the growing trade deficit (owing to the exchange-rate revaluation and greater openness at the start of the Real Plan). It should be noted that the most important non-tariff barriers were withdrawn in 1990 and, as a result, imports were mainly affected by tariffs and the exchange rate virtually throughout the decade.

The first of these stages witnessed two tariff reforms (June 1988 and September 1989) which reduced the redundant component of the nominal tariff without greatly altering the volume of imports. In 1990-1993 non-tariff barriers and special tax regimes were eliminated, and a timetable was applied for gradually lowering import duties. In 1994, the tariff reductions promoted at the start of the Real Plan were implemented, with a view to controlling domestic prices through greater external competition. In 19951998, the trade liberalization programme slackened, as tariffs were increased on certain consumer goods and administrative barriers to imports were reintroduced (Kume, Piani and Souza, 2000, pp. 3-4). ${ }^{2}$ Rates of duty were raised on imports of automobiles, motorcycles, bicycles, tractors, consumer electronic appliances, fabrics, blankets and sports footwear -goods that were causing the import expansion. At the same time, the Government lowered rates on another group of imports to avoid domestic price increases (Kume, Piani and Souza, 2000, p. 9).

\footnotetext{
2 These included the requirement for payment on demand in foreign purchases with external financing over less than a year, creation of a list of products for which prior import permits were required, and the application of safeguards.
} 
The MERCOSUR common external tariff entered into force in Brazil for most products in September 1994, ahead of the January 1995 date anticipated in the previous schedule (Baumann, Rivero and Zavattiero, 1997). This meant a loss of autonomy in the management of tariff policy. To implement the measures mentioned above, the Government had to include some of the products on their MERCOSUR schedule of national exemptions, which was later replaced by a new schedule with rates that were valid for a year. In general, the common external tariff prevented major changes in the tariff structure, which attained their greatest stability in the period 1995-1998. Lastly, in November 1997, the Government temporarily raised tariffs by $3 \%$ to reduce the current-account deficit, in response to the international financial crisis.

Trade barriers were thus progressively lowered to the point where they were confined basically to the established nominal tariffs, which had gradually become more uniform between the different sectors. This process is illustrated in figure 2, which was prepared using data on the average effective tariff weighted by free-trade value added in each sector, for the period 1987-1998. ${ }^{3}$

As the figure shows, the main reductions in the average effective tariff and its standard deviation occurred between 1987 and 1994, leading to more uniform protection in the various sectors of the economy and, hence, to a reduction in the distortions caused by such protection. After 1995, although average tariffs rose slightly, they remained around $18 \%$ in nominal terms and 20\% in effective terms (Kume, Piani and Souza, 2000, pp. 11 and 16).

The fact that those values were maintained, linked to the performance of production, suggests a favourable setting for induced import substitution through trade protection throughout the 1990s. To verify that hypothesis, the import substitution process needs to be quantified.

${ }^{3}$ The trend of the mean nominal tariff was not shown on the graph, since this behaves very similarly to the effective tariff, with a correlation of 0.87 between the two in the period analysed.

FIGURE 2

Brazil: Average effective tariff, 1987-1998

(Percentages)

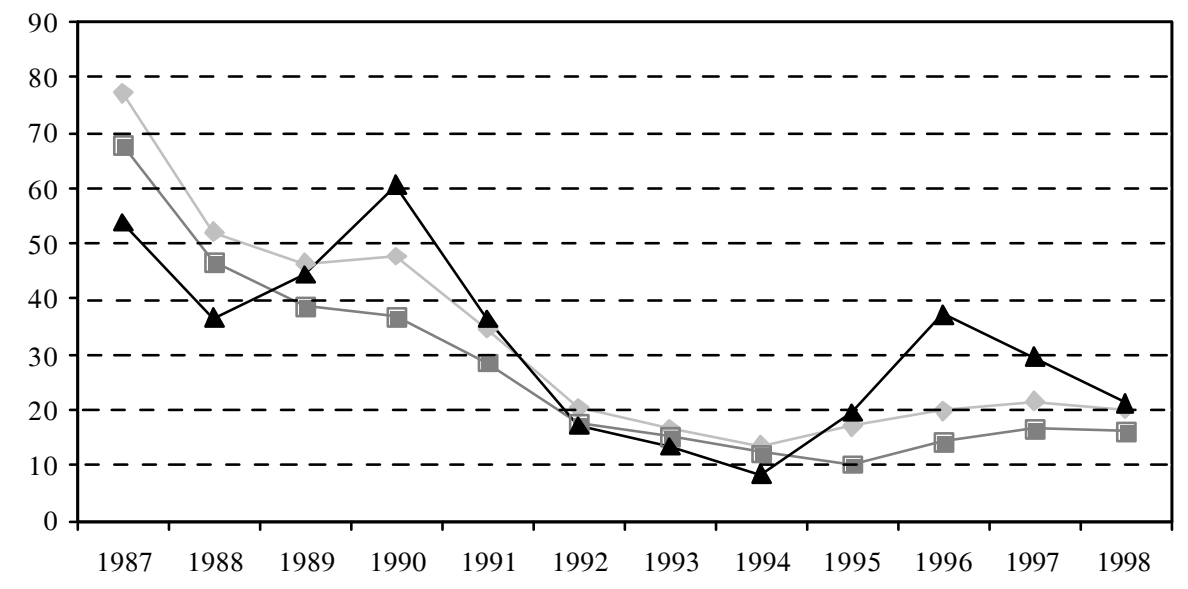

$\longrightarrow$ Simple average $\longrightarrow$ Average weighted by value added $\longrightarrow$ Standard deviation

Source: Authors' calculations using data from Kume, Piani and Souza (2000, p. 17). 


\section{IV}

\section{Methodology}

\section{Measuring the import substitution process}

There are several ways to make statistical calculations on import substitution (Desai, 1969) and thus link the effects of trade policies and the relation between the trade balance and domestic production in a given industry or sector, based on import and supply data for each item of merchandise in two successive time periods.

Imports and supply of $\operatorname{good} a$ in periods 1 and 2 will be identified as follows:

$\mathrm{M}^{a}{ }_{1}=$ imports of $\operatorname{good} a$ in period 1

$\mathrm{S}^{a}{ }_{1}=$ supply of $\operatorname{good} a$ in period 1

$\mathrm{M}^{a}{ }_{2}=$ imports of good $a$ in period 2

$\mathrm{S}^{a}{ }_{2}=$ supply of good $a$ in period 2 .

If $\mathrm{M}^{a}{ }_{2} / \mathrm{S}_{2}^{a}<\mathrm{M}^{a}{ }_{1} / \mathrm{S}^{a}{ }_{1}$, then import substitution occurred in period 2. On that basis, two import substitution measures are established -variant 1 and variant 2 .

\section{Variant 1}

One way to measure import substitution is to calculate the difference between the availability of imported products in the two selected periods, both in absolute terms (for variant $1 a$ ) and in relative terms (for variant $1 b)$. This makes it possible to construct two measures, defined as $S I_{1 a}$ and $S I_{1 b}$ :

$$
\begin{gathered}
S I_{1 a}=M_{2} / S_{2}-M_{1} / S_{1} \\
S I_{1 b}=\left(M_{2} / S_{2}-M_{1} / S_{1}\right) / M_{1} / S_{1}
\end{gathered}
$$

$S I_{1 a}$ is the variant $1 a$ measure of import substitution, which occurs in a given sector of industry when $M_{2} / S_{2}-M_{1} / S_{1}<0$. Comparing two sectors, import substitution will have been greater in the sector that has the lower $S I_{1 a}$ index.

$S I_{1 b}$ is the variant $1 b$ import-substitution measure, and is simply a version of $S I_{1 a}$ expressed in relative terms. Import substitution occurs when $\left(M_{2} / S_{2}-M_{1} /\right.$ $\left.S_{1}\right) / M_{1} / S_{1}<0$, i.e. when $S I_{1 b}$ is less than zero. Each of these measures has the disadvantage of being a decreasing function of the degree of import substitution in the sectors concerned. Import substitution is indicated by negative values of the $S I_{1 a}$ or $S I_{1 b}$ indices, so before they can be used in the regression analyses described below they need to be transformed into positive values: $S I_{i}=S I(-1)$, such that the larger the value of $S I_{i}$ the more intensive the process will have been.

\section{Variant 2}

Import substitution can be defined indirectly as the difference between the growth of a product without any change in the rate of imports, and the growth that actually took place.

Starting from the basic identity:

$$
Q+M \equiv R+D+E
$$

where:

$Q=$ domestic production

$M=$ imports

$R=$ demand for intermediate goods

$D=$ final domestic demand (including inventory building)

$E=$ exports

the following identity is obtained for the corresponding variations:

$$
\Delta Q+\Delta M=\Delta R+\Delta D+\Delta E
$$

If $S=Q+M=$ total supply, then $\Delta S=\Delta R+\Delta D+\Delta E$

Let us assume that $u_{1}=Q_{1} / S_{1}$ in the base year. If $u_{1}$ remains fixed, the variation in domestic production $\Delta Q$ is obtained from $u_{1} \cdot \Delta S$ or $u_{1} \cdot(\Delta R+\Delta D+\Delta E)$. If $u_{1}$ changes to $u_{2}=Q_{2} / S_{2}$, the variation will be:

$$
\Delta Q=u_{1}(\Delta R+\Delta D)+u_{1}(\Delta E)+\left(u_{2}-u_{1}\right) S_{2}
$$

Relation (3) divides the additional domestic production $(\Delta Q)$ into three parts:

a) $u_{1}(\Delta R+\Delta D)$ is the part destined for final and intermediate demand, according to the hypothesis that the domestically produced share of total supply does not change; 
b) $u_{1}(\Delta E)$ is the portion destined for exports, holding $u_{1}$ constant;

c) $\left(u_{2}-u_{1}\right) S_{2}$ is the variation in supply arising from the change in the share of domestic production in total supply.

The term $c$ measures the additional domestic production that would result exclusively from a change in the domestically produced share of total supply. That additional production, divided by the variation in domestic production $(\Delta Q)$, becomes variant 2 expressed by $\mathrm{SI}_{2}$ to measure import substitution:

$$
S I_{2}=\left(u_{2}-u_{1}\right) S_{2} / \Delta Q
$$

According to this measure, import substitution occurs when $\left(u_{2}-u_{1}\right) S_{2} /(\Delta Q)$ is greater than zero (i.e. when $S I_{2}>0$ ).

According to Desai (1969) the measures $S I_{\mathrm{A}}, S I_{\mathrm{B}}$ and $\mathrm{SI}_{2}$-all based on changes in import rates with respect to the base year- should theoretically change in the same direction, whether there was import substitution or not. Nonetheless, the magnitude of the effects of import substitution and the ranking of sectors may vary according to the measure used. The values obtained with the measures $S I_{\mathrm{B}}$ and $S I_{2}$ proved unsuitable for this article for the following reasons: (i) the variations observed in $S I_{\mathrm{B}}$ were largely due to the weighting that this measure receives $\left(1 /\left(M_{1} / S_{1}\right)\right.$ and could not be explained by exchange-rate and tariff variables; (ii) the measure $S I_{2}$ displayed large discrepancies with respect to the results of $S I_{\mathrm{A}}$ and $S I_{\mathrm{B}}$ because the value of domestic production in certain sectors (at constant 1998 prices) decreased between the two periods, suggesting the presence of an importsubstitution process when what really happened was that the denominator of this index $\left(Q_{2}-Q_{1}\right)$ changed sign. For that reason, the index of import substitution used in this paper is the $S I_{\mathrm{A}}$ measure.

Using the Moreira and Puga (2001) database, $S I_{\mathrm{A}}$ measures were calculated for the periods 1989-1994, 1994-1998, 1998-2000 and 1989-2000 with respect to seven categories of use (table 2).

The choice of periods reflects the phases in Brazil's economic liberalization process since the late 1980s. The first period (1989-1994) was when the main changes in the trade regime took place, including the largest cuts in tariff barriers. In the second period (19941998) the liberalization process slackened slightly (see figure 2 above). In 1998-2000, devaluation of the real in January 1999 added a new ingredient to the analysis
TABLE 2

Brazil: Values of the $S I_{A}$ measure of import substitution in the economy ${ }^{\mathrm{a}}$

\begin{tabular}{lr}
\hline Period and Industry Group & $S I_{\mathrm{A}}$ \\
\hline 1989-1994 & \\
Consumer durables & -9.35 \\
Consumer non-durables & -4.25 \\
Intermediate goods & -7.62 \\
Processed intermediate goods & -10.42 \\
Capital goods & -21.80 \\
Transport equipment & -14.79 \\
Industry total & -9.82
\end{tabular}

1994-1998

Consumer durables

Consumer non-durables

$-0.24$

Intermediate goods

0.81

Processed intermediate goods

$-2.40$

Capital goods

$-13.93$

Transport equipment

$-1.37$

Industry total

$-1.94$

1998-2000

Consumer durables

Consumer non-durables

Intermediate goods

$-1.07$

Processed intermediate goods $\quad 2.34$

Capital goods

0.44

Transport equipment

4.94

Industry total

1.55

1989-2000

Consumer durables

Consumer non-durables

Intermediate goods

Processed intermediate goods

$-7.88$

Capital goods

$-10.48$

Transport equipment

$-35.29$

Industry total

$-11.22$

$-10.21$

Source: Authors' calculations on the basis of data from Moreira and Puga (2001).

${ }^{\text {a }}$ See the text for the definition of the measure used.

of the country's foreign trade results. The results for this period can also be compared with those obtained by Moreira and Puga (2001). The calculation of the $S I_{\mathrm{A}}$ indices for 1989-2000 is also important, since it relates two quite different periods in terms of the country's external policy: the base year is 1989, when trade barriers still prevailed, and this is compared with 2000 when the economy was more open to trade and more competitive as a result of exchange-rate variations.

Table 2 shows that in the period 1989-1994 there was no import substitution in any of the categories 
analysed. On the contrary, the import share increased and the domestically produced share of total supply declined. This is as expected, because the economy was exposed to major external competition in that period, resulting from the appreciation of the real and the price and wealth effects caused by domestic price stabilization.

The rising share of imports in total supply was not reversed in the period 1994-1998, except in the intermediate goods sector, when import substitution occurred on a minor scale.

According to table 2, the sectors in which import substitution occurred in 1998-2000, were as follows, in order of importance: transport equipment, processed intermediate goods, consumer durables, consumer nondurables and capital goods. The only sector in which there was no import substitution according to the $S I_{\mathrm{A}}$ measure was intermediate goods. The results obtained by Moreira and Puga (2001) were not identical to those obtained with the $S I_{\mathrm{A}}$ measure in terms of the incidence and intensity of the import substitution process in the different sectors throughout the period studied. ${ }^{4}$ Nonetheless, the two approaches agree that there was an import-substitution process in manufacturing industry as a whole in 1998-2000. This was most pronounced in the transport equipment sector, followed by processed intermediate goods, whereas no import substitution occurred in the intermediate goods sector.

Comparing 1989 with 2000, the indices in all sectors were negative and their absolute values very large. Whereas in 1989 the average effective tariff in manufacturing industry was roughly $70 \%$, by 2000 it had dropped to about $20 \%$ (see again figure 2). The $S I_{\mathrm{A}}$ indices for that period show that there was no import substitution and that the domestically produced share of total supply shrank considerably, owing to the economy's greater exposure to international competition.

Consequently, the effects of import substitution were concentrated mostly in the final years of the series, between 1998 and 2000. As the exchange rate depreciated sharply in January 1999, without this attenuating the tariff-reduction process (and thus maintaining the level of effective protection in the

\footnotetext{
${ }^{4}$ According to Moreira and Puga (2001), the sectors in which import substitution occurred in 1998-2000, in order of importance (greatest reduction in the import/apparent consumption ratio), were: transport equipment (26.8\% reduction), processed intermediate goods (14\% reduction) and consumer non-durables (10.5\% reduction). The sectors in which the import coefficient increased during 1998-2000 were: consumer durables (24\%), intermediate goods (11.54\%) and capital goods $(3.5 \%)$.
}

different sectors), it can be assumed that import substitution in those years was essentially spontaneous, i.e. derived from the competitiveness of domestic production linked to the exchange-rate variation.

\section{Relation between tariffs, the exchange rate and import substitution}

To determine whether variations in import-substitution indices in the various sectors reflected changes in tariff levels and exchange rates, the corresponding variables were analysed for certain sectors of manufacturing industry in the period 1995-2000. The analysis does not include the previous period because, as shown in table 2, there was no import substitution between 1989 and 1994. Moreover, given the sharp devaluation of the real in 1999, it is in the1995-2000 period that one sees phenomena that could have contributed both to induced import substitution (in response to tariff policy) and to natural import substitution reflecting the exchange-rate depreciation that occurred from 1999 onwards).

The exchange-rate indicator used is the real effective exchange rate index published by Boletim Funcex de câmbio (1998 and 2002). This is calculated on the basis of the real exchange rates of Brazil's 13 leading trade partners, weighted by the each country's average share in Brazil's trade flow (imports and exports) (table 3 ). For the purposes of this article, that exchange rate measure has an advantage over bilateral exchange rates with other countries. ${ }^{5}$

To analyse the effect of the variables "exchange rate" and "effective tariff" on the import substitution index, a regression was performed using data from the period 19952000, covering 34 of the 49 industrial sectors for which

TABLE 3

Brazil: Real effective exchange rate index (R\$/basket of 13 currencies)

(August $1994=100)$

\begin{tabular}{lr}
\hline Year & Index \\
\hline 1995 & 96.1 \\
1996 & 99.1 \\
1997 & 94.6 \\
1998 & 99.8 \\
1999 & 116.4 \\
2000 & 107.2 \\
\hline
\end{tabular}

Source: Up to 1997, Boletim Funcex de câmbio (1998); for 1998-2000, Boletim Funcex de câmbio (2002).

\footnotetext{
${ }^{5}$ The real effective exchange rate reflects changes in the purchasing power of the local currency compared to the currencies of Brazil's leading trade partners, for which reason it is assumed to have more influence over the country's import and export flows.
} 
data were available. The figures on effective tariffs were taken from Kume, Piani and Souza (2000). Table 4 shows the $S I_{\mathrm{A}}$ indices for the 34 sectors analysed.

Performing the desired analysis required tariff values for 1999 and 2000. As these data were not available, an approximation was made by arbitrarily assuming that the structure of the effective tariff had not changed since 1998 .

The hypothesis underlying this simulation is that the tariff-reduction process stabilized in most sectors as from 1995, since, according to Kume, Piani and Souza (2000), in 1998 the variations in observed nominal tariffs were already very small compared to the those of the previous year.

To process those data, we will use panel analysis as described below. a) Statistical models for panel data with one factor Observations on a response variable of interest $y$, and a vector $\boldsymbol{x}$ of explanatory variables for $\boldsymbol{N}$ different sectors of the economy in each of $T$ successive years $(t)$, constitute a panel data set. ${ }^{6}$ Various linear regression models have been proposed for this type of data. In general, the model establishes that, for a given

\footnotetext{
${ }^{6}$ The main advantage of the panel dataset is that it allows great flexibility in defining differences of behaviour between units such as the target sectors of this paper. The specific effects represent singular characteristics of each group, either observable (inputs with more intensive technology use, use of imported inputs, and others), or non-observable (management ability, among others), and are assumed constant throughout time (which does not necessarily mean that they are non-stochastic).
}

TABLE 4

Brazil: $S I_{A}$ indices for 34 sectors of manufacturing industry, 1995-2000

\begin{tabular}{|c|c|c|c|c|c|c|}
\hline Sector & 1995 & 1996 & 1997 & 1998 & 1999 & 2000 \\
\hline Iron and steel & -1.82 & 0.54 & -1.00 & -1.19 & 2.40 & -0.61 \\
\hline Non-ferrous metallurgy & -7.41 & 2.71 & -3.05 & 0.05 & 3.57 & -1.22 \\
\hline Other metallurgical products & -2.65 & -2.67 & -2.78 & 0.32 & 2.75 & 0.76 \\
\hline Tractors and road-building machinery, parts and accessories & -4.99 & 1.37 & -7.49 & -3.24 & 5.44 & 1.36 \\
\hline Conductors and other electric materials, except for vehicles & -1.34 & -4.13 & -7.64 & -4.51 & 0.48 & -1.72 \\
\hline Electronic and communications material and appliances & -8.34 & -2.83 & -6.10 & -8.69 & -5.14 & -2.28 \\
\hline Automobiles, trucks and buses & -13.68 & 12.52 & -6.78 & -6.28 & 11.97 & 0.26 \\
\hline Engines and vehicle parts & -8.01 & 0.06 & 2.39 & 8.33 & 13.49 & -2.52 \\
\hline Other vehicles & -6.60 & -4.05 & -13.60 & -2.48 & 2.38 & -3.05 \\
\hline Wood industry & -0.72 & -1.75 & -2.73 & 0.89 & 3.74 & 0.10 \\
\hline Cellulose and mechanical pulp & -0.86 & 0.14 & -0.22 & -0.25 & 0.24 & -0.13 \\
\hline Paper, cardboard and paper articles & -10.71 & 2.12 & -0.48 & -1.22 & 6.36 & -0.18 \\
\hline Rubber industry & -6.65 & 0.85 & -2.29 & -0.73 & 5.08 & -0.60 \\
\hline Chemical elements (excluding petrochemicals or carbon-based chemicals) & -7.81 & -1.54 & -0.32 & -0.76 & 4.93 & 3.05 \\
\hline Refined petroleum & -6.74 & -6.13 & -0.52 & 4.47 & 0.76 & -6.17 \\
\hline Miscellaneous chemical products & -4.88 & -0.25 & -2.24 & -1.05 & 1.54 & 0.10 \\
\hline Pharmaceutical industry & -7.38 & -5.27 & -4.03 & -5.08 & -4.92 & 3.68 \\
\hline Perfume, soaps and candle industry & -1.89 & 0.14 & -0.83 & -0.47 & 0.30 & 0.11 \\
\hline Plastic sheeting & -1.96 & 0.80 & 0.56 & -0.35 & 0.31 & -0.30 \\
\hline Plastic articles & -7.78 & -3.15 & -3.33 & 0.60 & 1.64 & -0.30 \\
\hline Processing, sewing and weaving of natural fibres & -3.67 & -4.11 & 0.71 & 4.76 & 3.65 & 1.19 \\
\hline Sewing and weaving of artificial or synthetic fibres & -7.24 & 3.71 & -0.94 & -0.01 & 0.17 & -2.25 \\
\hline Other textile industries & -5.38 & -0.92 & -4.75 & -0.66 & 2.10 & -1.01 \\
\hline Clothing and accessories & -3.50 & 0.12 & -0.75 & 0.82 & 2.15 & 0.20 \\
\hline Footwear & -1.35 & 0.31 & 0.00 & 1.02 & 0.67 & 0.12 \\
\hline Coffee industry & -0.07 & 0.01 & -0.03 & 0.07 & -0.01 & 0.00 \\
\hline Wheat milling & -2.16 & 11.47 & -10.94 & 2.40 & 1.22 & -4.16 \\
\hline Fruit and vegetable preserves, juices and condiments & -1.12 & 0.52 & -0.35 & 0.28 & 0.65 & 0.27 \\
\hline Animal slaughtering and preparation of meats & -1.95 & 3.54 & -2.12 & 1.40 & 5.39 & -1.67 \\
\hline Poultry slaughtering and preparation & -0.03 & 0.01 & -0.02 & 0.00 & 0.04 & -0.01 \\
\hline Refrigeration and preparation of milk and dairy products & -4.05 & 1.88 & 0.99 & -0.70 & 0.52 & 0.77 \\
\hline Sugar industry & 0.14 & 0.15 & 0.18 & 0.04 & -0.03 & -0.10 \\
\hline Refining of vegetable oils and manufacture of fats for foodstuffs & -2.58 & -3.72 & 1.30 & -1.93 & 5.09 & 0.32 \\
\hline Other food industries & -9.80 & -1.54 & 1.89 & 0.67 & 6.44 & 1.04 \\
\hline
\end{tabular}

Source: Authors' calculations on the basis of data from Moreira and Puga (2001). See the text for the definition of the measure used. 
sector $i$ in a given period $t$, the response $y(i, t)$ is related to the coefficients $a_{i}$, the vector of variables $\boldsymbol{x}(i, t)$ and random disturbances e $(i, t)$, according to the following expression:

$$
\begin{gathered}
y(i, t)=a_{\mathrm{i}}+\boldsymbol{b}(i) \boldsymbol{x}(i, t)+e(i, t), \\
\text { for } i=1 \ldots N ., t=\ldots T .
\end{gathered}
$$

The various models proposed in the specialist literature make different assumptions on the coefficients $a_{i}$, the vectors of coefficients $b(i)$ and the distribution of random terms $e(i, t)$ (Greene, 1997, p. 612). In this paper, the different sectors were allowed to have different $a_{i}$ intercepts, but the regression coefficients $b(i)$ with respect to the variables $x$ (estimation of which is the main purpose of the panel data analysis) are the same for the various sectors, i.e. $b(i)=b$ for $i=1 \ldots N$. It was thus assumed that the various sectors respond with the same velocity to variations in tariffs and the exchange rate, although they may have different initial response levels. This is known as a sectoral "fixed

\section{V}

\section{Results}

The sudden change in the exchange-rate plateau in 1999 probably altered its effect on the import substitution index $S I_{\mathrm{A}}$, which led to the decision to analyse the periods 1995-1998 and 1999-2000 separately. The fitted models were referred to as regression I and regression II, respectively.

In the first period studied (1995-1998) the sector effects were considerable; the values of the fixed effects $a_{i}$ $(i=1 \ldots 34)$ for each of the 34 sectors analysed are detailed in table 5. The average of those values was -68.04.

As the observations are heterogeneous, the appropriate covariance matrix was estimated using the White matrix, and the value of $R^{2}$ was 0.51 .

Table 6 shows the values of the coefficients of regression I (1995-1998) for the explanatory variables; the coefficients on the tariff and exchange-rate are positive and significant.

In the final fitted model $S I_{\mathrm{A}}$ depends on specific fixed effects of the tariff and exchange rate for the sectors:

$$
\begin{gathered}
S I_{\mathrm{A}}(i, t)=a_{i}+0.2143 \text { Tariff }+0.6341 \\
\text { Exchange rate }+e(i, t) .
\end{gathered}
$$

effects" model. ${ }^{7}$ When, in addition to specifying a different intercept for each sector, it is also assumed that the covariance matrix of the disturbances $e(i, t)$ is diagonal and homoscedastic, the coefficients $a_{i}$ and $b$ can be calculated using ordinary least squares, with dummy variables indicating the various sectors. If the covariance matrix of the disturbances $e(i, t)$ is diagonal and heteroscedastic, the coefficients $a_{i}$ and $b$ can also be calculated by least squares; but a robust estimation of the covariance matrix for the $b$ estimators will need to be made, e.g. using the White matrix (Greene 1997, p. 635).

The fixed effects model was thus used for panel data to infer the repercussions of tariff changes and exchange-rate movements on the import substitution index $S I_{\mathrm{A}}$ for the 34 industry sectors studied. After adapting a model with different fixed effects for each sector, a test was made on the null hypothesis $\left(H_{0}\right)$ of equal constants $a_{i}$. If the test indicates acceptance of $H_{0}$ the final model will be a regression with the same basic intercept, $y(i, t)=a+b x(i, t)+e(i, t)$.

In the 1999-2000 period (regression II), the sectors effect was not significant, such that in the final fitted model, $S I_{\mathrm{A}}$ only depends on an intercept $a$ (which is common to all sectors) along with the explanatory variables "tariff" and "exchange rate".

Table 7 shows the regression II coefficients for the explanatory variables. The value of $R^{2}$ was 0.2923 .

The intercept $a$ and the coefficients on the tariff and exchange rate are significant in the second period (regression II).

Consequently, the fitted model (regression II) was:

$$
\begin{aligned}
S I_{\mathrm{A}}(i, t)= & 35.8650+0.0486 \text { Tariff }+0.3207 \\
& \text { Exchange rate }+e(i, t) .
\end{aligned}
$$

\footnotetext{
${ }^{7}$ Some models also consider the randomness of the vector of $b$ parameters between the cross-section units. These are an extension of simpler fixed and random effects models for panel data. The main difficulty in applying such "random-coefficient models" is that the panel normally refers to short time periods, so there are few observations with which to calculate $b_{i}$. For further details on this methodology, see Greene (2002, p. 309) and Pesaran and Smith (1995).
} 
TABLE 5

Brazil: Values of sector fixed effects $\left(a_{i}\right)$ in the first regression

\begin{tabular}{|c|c|c|c|c|}
\hline & Sector & Effect & $\mathrm{SD}^{\mathrm{a}}$ & $t$ \\
\hline 1 & Iron and steel & -65.24 & 10.78 & -6.05 \\
\hline 2 & Non-ferrous metallurgy & -65.92 & 10.79 & -6.11 \\
\hline 3 & Other metallurgical products & -68.68 & 10.75 & -6.39 \\
\hline 4 & Tractors and road-building machinery, parts and accessories & -69.20 & 10.76 & -6.43 \\
\hline 5 & Conductors and other electric materials, except for vehicles & -71.71 & 10.75 & -6.67 \\
\hline 6 & Electronic and communications material and appliances & -72.23 & 10.76 & -6.71 \\
\hline 7 & Automobiles, trucks and buses & -99.47 & 11.06 & -8.99 \\
\hline 8 & Engines and vehicle parts & -65.43 & 10.76 & -6.08 \\
\hline 9 & Other vehicles & -72.81 & 10.76 & -6.77 \\
\hline 10 & Wood industry & -65.71 & 10.78 & -6.10 \\
\hline 11 & Cellulose and mechanical pulp & -64.71 & 10.78 & -6.00 \\
\hline 12 & Paper, cardboard and paper articles & -66.98 & 10.78 & -6.21 \\
\hline 13 & Rubber industry & -67.24 & 10.77 & -6.24 \\
\hline 14 & Chemical elements (excluding petrochemicals or carbon-based chemicals) & -67.30 & 10.78 & -6.25 \\
\hline 15 & Refined petroleum & -65.01 & 10.80 & -6.02 \\
\hline 16 & Miscellaneous chemical products & -66.18 & 10.78 & -6.14 \\
\hline 17 & Pharmaceutical industry & -69.06 & 10.79 & -6.40 \\
\hline 18 & Perfume, soaps and candle industry & -64.38 & 10.79 & -5.97 \\
\hline 19 & Plastic sheeting & -66.50 & 10.76 & -6.18 \\
\hline 20 & Plastic articles & -69.68 & 10.76 & -6.48 \\
\hline 21 & Processing, sewing and weaving of natural fibres & -67.34 & 10.75 & -6.26 \\
\hline 22 & Sewing and weaving of artificial or synthetic fibres & -67.89 & 10.75 & -6.31 \\
\hline 23 & Other textile industries & -69.69 & 10.75 & -6.48 \\
\hline 24 & Clothing and accessories & -67.88 & 10.75 & -6.32 \\
\hline 25 & Footwear & -66.17 & 10.76 & -6.15 \\
\hline 26 & Coffee industry & -64.62 & 10.78 & -6.00 \\
\hline 27 & Wheat milling & -65.63 & 10.76 & -6.10 \\
\hline 28 & Fruit and vegetable preserves, juices and condiments & -65.99 & 10.76 & -6.13 \\
\hline 29 & Animal slaughtering and preparation of meats & -63.78 & 10.79 & -5.91 \\
\hline 30 & Poultry slaughtering and preparation & -64.01 & 10.79 & -5.93 \\
\hline 31 & Refrigeration and preparation of milk and dairy products & -66.78 & 10.76 & -6.21 \\
\hline 32 & Sugar industry & -65.56 & 10.76 & -6.09 \\
\hline 33 & Refining of vegetable oils and manufacture of fats for food & -65.63 & 10.79 & -6.08 \\
\hline 34 & Other food industries & -68.79 & 10.75 & -6.40 \\
\hline
\end{tabular}

Average value of sector fixed effects $=-68.04$

Source: Authors' calculations.

a $\mathrm{SD}=$ Standard deviation

TABLE 6

Brazil: Values of regression I parameters, $\boldsymbol{t}$-statistic and significance level $\boldsymbol{P}$

\begin{tabular}{|c|c|c|c|c|c|}
\hline Variable & Coefficient & Estimate & $\mathrm{SD}^{\mathrm{a}}$ & $t_{0}$ & $P\left[t>t_{0}\right]$ \\
\hline Tariff & $b_{1}$ & 0.2143 & 0.0270 & 7.943 & 0.0000 \\
\hline Exchange rate & $b_{2}$ & 0.6341 & 0.1099 & 5.770 & 0.0000 \\
\hline
\end{tabular}

Source: Authors' calculations.

${ }^{a}$ Standard deviation obtained from the White covariance matrix. 
TABLE 7

Brazil: Values of regression II parameters, $t$-statistic and significance level $P$

\begin{tabular}{|c|c|c|c|c|c|}
\hline Variable & Coefficient & Estimate & $\mathrm{SD}^{\mathrm{a}}$ & $t_{0}$ & $P\left[\mid t>t_{0}\right]$ \\
\hline Tariff & $b_{1}$ & 0.0486 & 0.0174 & 2.801 & 0.0067 \\
\hline Exchange rate & $b_{2}$ & 0.3207 & 0.0736 & 4.358 & 0.0000 \\
\hline Intercept & $A$ & 35.8650 & 8.2425 & -4.351 & 0.0000 \\
\hline
\end{tabular}

Source: Authors' calculations.

a Standard deviation obtained from the White covariance matrix.

Comparing the data of table 6 and 7 reveals that the coefficients of the explanatory variables "tariff" and "exchange rate" decreased in the second period, and the regression $R^{2}$ dropped from 0.5081 to 0.2923 . This suggests that other variables apart from those considered in this paper had a greater effect on the behaviour of $S I_{\mathrm{A}}$ in that period.

The influence of the explanatory variables "effective tariff" and "exchange rate" on the import substitution index will be now be analysed.

A simple review of the regression coefficients estimated after fitting a model is not sufficient to decide which of the explanatory variables causes the largest change in the response variable. This is because of the difference between the distributions of the explanatory variables, which can be inferred from the data in table 8 on the value of the mean, standard deviation and mean plus half a standard deviation of the explanatory variables "tariff" and "exchange rate", with respect to the dataset used in regression I.

Table 9 shows the same information for the data used in regression II.

The value of the predicted $S I_{\mathrm{A}}$ index was calculated on the basis of parameters estimated in regressions I and II for the variables tariff and exchange rate (table 7 and 8), and the values of the mean and standard deviation of these variables in the period 19951998 and 1999-2000 (tables 9 and 10).

According to regression I, when the values of the effective tariff and exchange rate are equal to their respective mean values in the period analysed, the predicted value of $S I_{\mathrm{A}}$ is -1.7951 . When half a standard deviation is added to the average tariff and the mean value of the exchange rate is held constant, the predicted $S I_{\mathrm{A}}$ rises to 0.9782 . When half a standard deviation is added to the mean of the exchange rate, holding the average value of the tariff constant, the predicted $S I_{\mathrm{A}}$ falls to -1.118. Consequently, according to regression I, which uses data from the first period analysed (1995-1998), the effective tariff variable exerted a greater influence on variations in the $S I_{\mathrm{A}}$ index
TABLE 8

\section{Brazil: Statistics on the distribution of the effective tariff and exchange rate in regression I}

\begin{tabular}{lrr}
\hline & Tariff & $\begin{array}{c}\text { Exchange } \\
\text { rate }\end{array}$ \\
\hline Mean & 20.89 & 97.40 \\
Standard deviation & 25.89 & 2.13 \\
Mean +0.5 SD & 33.84 & 98.47 \\
\hline
\end{tabular}

Source: Authors' calculations.

TABLE 9

Brazil: Statistics on the distribution of the effective tariff and exchange rate in regression II

\begin{tabular}{lrr}
\hline & Tariff & $\begin{array}{c}\text { Exchange } \\
\text { rate }\end{array}$ \\
\hline Mean & 21.49 & 111.80 \\
Standard deviation & 19.65 & 4.63 \\
Mean +0.5 SD & 31.31 & 114.12 \\
\hline
\end{tabular}

Source: Authors' calculations.

than the exchange rate variable. These data are summarized in table 10 .

In regression II, the predicted $S I_{\mathrm{A}}$ index, based on values of the average tariff and exchange rate in the period (table 9), is 1.034. Adding half a standard deviation to the average tariff and holding the mean value of the exchange rate constant raises the predicted $S I_{\mathrm{A}}$ to 1.511 . When half a standard deviation is added to the average exchange rate, holding the mean value of the tariff constant, the predicted $S I_{\mathrm{A}}$ rises to 1.7803 . Consequently, according to regression II, which corresponds to 1999-2000, the exchange-rate variable exerts greater influence on variations in the $S I_{\mathrm{A}}$ index and the effective tariff variable. These data are summarized in table 11.

These results show that variations in effective tariffs and the exchange rate influenced the $S I_{\mathrm{A}}$ index throughout the period analysed (1995-2000), and that $S I_{\mathrm{A}}$ is a rising function both of the exchange rate and of the effective tariff level in the 34 sectors of 
TABLE 10

Brazil: Predicted $S I_{A}$ index in regression I for selected values of the explanatory variables "effective tariff" and "exchange-rate", in 1995-1998

\begin{tabular}{|c|c|c|}
\hline Effective tariff & Exchange-rate & Predicted $S I_{\mathrm{A}}$ Index \\
\hline $\begin{array}{l}\mathrm{M}_{\text {TARIFF }} \\
\mathrm{M}_{\text {TARIFF }}+0.5 \mathrm{SD}_{\text {TARIFF }} \\
\mathrm{M}_{\text {TARIFF }}\end{array}$ & $\begin{array}{ll}M_{\text {EXCHANGE }} & \text { RATE } \\
M_{\text {EXChANGE }} & \text { RATE } \\
M_{\text {EXCHANGE }} & \text { RATE }+0.5 \mathrm{SD}_{\text {EXCHANGE RATE }}\end{array}$ & $\begin{array}{l}-1.7951 \\
0.9782 \\
-1.118\end{array}$ \\
\hline
\end{tabular}

Source: Authors' calculations.

${ }^{\mathrm{a}} \mathrm{M}=$ Mean; $\mathrm{SD}=$ Standard deviation.

TABLE 11

Brazil: Predicted $S I_{A}$ index in regression II for selected values of the explanatory variables "effective tariff" and "exchange rate", in 1999-2000"

\begin{tabular}{|c|c|c|}
\hline Effective tariff & Exchange-rate & Predicted $S I_{\mathrm{A}}$ Index \\
\hline $\begin{array}{l}\mathrm{M}_{\text {TARIFF }} \\
\mathrm{M}_{\text {TARIFF }}+0.5 \mathrm{SD}_{\text {TARIFF }} \\
\mathrm{M}_{\text {TARIFF }}\end{array}$ & $\begin{array}{ll}\mathrm{M}_{\text {EXCHANGE }} & \text { RATE } \\
\mathrm{M}_{\text {EXCHANGE }} & \text { RATE } \\
\mathrm{M}_{\text {EXCHANGE }} & \text { RATE }+0.5 \mathrm{SD} \\
\text { EXCHANGE RATE }\end{array}$ & $\begin{array}{l}1.034 \\
1.511 \\
1.7803\end{array}$ \\
\hline
\end{tabular}

Source: Authors' calculations.

${ }^{\mathrm{a}} \mathrm{M}=$ Mean; $\mathrm{SD}=$ Standard deviation

manufacturing industries studied. Nonetheless, intersectoral fluctuations of the $S I_{\mathrm{A}}$ index in the period prior to the devaluation (1995-1998) were more reflective of inter-sectoral fluctuations in effective tariff levels, whereas in the subsequent period (19992000) they mainly responded to exchange-rate movements. This result means that if 1995-1998 was the period of greatest stability in nominal and effective tariffs in the last decade, and this lasted until 2000, the exchange-rate variation observed as from January 1999 was mainly responsible for the import

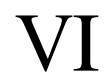

\section{Conclusions}

This paper has used regression analysis to evaluate the influence of the effective tariff and real effective exchange rate on the import substitution index $\left(S I_{\mathrm{A}}\right)$ during the period 1995-2000. The analysis shows that the two variables had considerable repercussions on variations in that index. From 1999 onwards, the real effective exchange rate had a greater effect than the effective tariff, since nominal and effective tariffs varied very little after 1998, while the exchange rate depreciated sharply in January 1999. This suggests that the import substitution in those sectors in 1999 and 2000, compared to 1998.

Thus the import substitution that occurred in 19951998 was induced by the maintenance of significant tariffs (trade liberalization measures notwithstanding) and a degree of dispersion in the tariff structure, which resulted in significant levels of effective protection. After 1999, following the sharp exchange-rate devaluation, the relative price effect was stronger than protection as a force inducing import substitution, the pace of which slackened following the revaluation of the real in 2000. substitution process of the recent period was probably natural or spontaneous rather than induced.

This is a significant result, because it highlights the importance of productive sectors' having welladjusted relative prices. Greater transparency in market signals is what makes it possible to efficiently exploit an economy's comparative advantages, just as international trade theory teaches.

(Original: Portuguese) 
Alem, A.C., J.R.M. Barros and F. Giambiagi (2002): Bases para uma política industrial moderna, Estudos e pesquisas, No. 22, Rio de Janeiro, Fórum Nacional. Available in: $<$ http://www.forumnacional.org.br/publi/pestpq1.asp $>$.

Barros, J.R.M. and L. Goldenstein (1997): Avaliação do processo de reestruturação industrial brasileiro, Revista de economia política, vol. 17(2), No. 66, São Paulo, Centro de Economia Política, April-June.

Baumann, R., J. Rivero and Y. Zavattiero (1997): As tarifas de importação no Plano Real, Pesquisa e planejamento econômico, vol. 27, No. 3, Rio de Janeiro, Institute of Applied Economic Research (IPEA), December.

Boletim FUNCEX de câmbio (1998): year 7, No. 10, Rio de Janeiro, Fundação Centre for Foreign Trade Studies (FUNCEX), November-December.

(2002): año 22, $\mathrm{N}^{\circ}$ 2, Rio de Janeiro, Fundação Centro de Estudos do Comércio Exterior (FUNCEX), febrero.

Bruton, H. (1989): Import substitution, in H. Chenery and T.N. Srinivasan (eds.), Handbook of International Economics, vol. 2, Amsterdam, North Holland.

Desai, P. (1969): Alternative measures of import substitution, Oxford Economic Papers, vol. 21, No. 3, Oxford, Oxford University Press.

Díaz-Alejandro, C.F. (1975): Trade, policies and economic development, in P. Kenen (ed.), International Trade and Finance: Frontiers for Research, Cambridge, Cambridge University Press.

Greene, W.H. (1997): Econometric Analysis, third edition, London, Prentice Hall.
(2003): Econometric Analysis, fifth edition, London, Prentice Hall.

Kume, H., G. Piani and C.F.B. Souza (2000): A política brasileira no período 1987-98: descrição e avaliação, Rio de Janeiro, Institute of Applied Economic Research (IPEA), May.

Levy, P.M. and M.I.F. Serra (2002): Coeficientes de importação e exportação na indústria, Boletim de conjuntura, No. 58, Rio de Janeiro, Institute of Applied Economic Research (IPEA), July-August.

Melo, P.R.S., E.C.S.D. Rios and R.M.V. Gutiérrez (2001): Componentes eletrônicos: perspectivas para o Brasil, BNDES Setorial, No. 13, Rio de Janeiro, Banco Nacional de Desenvolvimento Econômico e Social (BNDES), March.

Moreira, M.M. and F.P. Puga (2001): Coeficientes de comércio em 2000: o desafio externo, Nota técnica AP/DEPEC, No. 4 Rio de Janeiro, Banco Nacional de Desenvolvimento Econômico e Social (BNDES), May.

Pesaran, M.H. and R.J. Smith (1995): Estimating long-run relationships from dynamic heterogeneous panels, Journal of Econometrics, No. 68, Amsterdam, Elsevier.

Rosa, S.E.S. (2001): Evolução histórica e perspectivas da indústria brasileira de componentes eletrônicos, Rio de Janeiro, COPPE/ Rio de Janeiro's Federal University, August.

Tavares, M.C. (1977): Auge e declínio do processo de substituição de importações no Brasil, in M.C. Tavares, Da substituição de importações ao capitalismo financeiro, sixth edition, Rio de Janeiro, Zahar. 